\title{
A study of relations between gender and careers anchors
}

\author{
ADRIANE VIEIRA ${ }^{1}$ \\ Plínio RAFAel ReIS MONTEIRO ${ }^{2}$ \\ ALEXANDRE de PÁdUA CARRIERI ${ }^{2}$ \\ VANESSA DE ALMEIDA GUERRA ${ }^{1}$ \\ LUIZ CARLOS BRANT ${ }^{1}$
}

${ }^{1}$ Universidade Federal de Minas Gerais (UFMG) / Curso de Gestão de Serviços de Saúde da Escola de Enfermagem (EE),

BELO HORIZONTE - MG, BRAZIL

2 Universidade Federal de Minas Gerais (UFMG) / Departamento de ClênCias Administrativas, Curso de AdministraçÃo,

BELO HORIZONTE - MG, BRAZIL

\begin{abstract}
The research analyzed the relationship between gender and career anchors of undergraduate students, using the survey method. The sample totaled 251 Engineering students and 251 Health Care students. To collect the data, we used questionnaires containing the Inventory Career Guidance of Schein (1990). The analysis techniques used were descriptive statistics and exploratory factor analysis. The results show that, in the Engineering area, female respondents valued more the lifestyle and safety anchors, whose attributes are socially associated with the female gender. In the area of Health Care, male respondents valued more autonomy and independency, pure challenge, and creativity anchors, whose attributes are associated with the male gender. We conclude that career choices are strongly associated with the values and attributes socially assigned to gender.
\end{abstract}

Keywords: Career anchors. Genre. Professions. Health. Engineering.

\section{Um estudo das relações entre gênero e âncoras de carreira}

\section{Resumo}

Este artigo analisa a relação entre gênero e âncoras de carreira de estudantes de cursos de graduação em que predominam o gênero feminino ou o masculino. O método adotado foi o levantamento (survey). A amostra englobou 251 graduandos da área de Engenharia e 251 da área de Saúde. Os dados foram coletados por meio de questionários contendo o "Inventário de Orientação de Carreira" (IOC), de Schein (1990). As técnicas aplicadas foram a estatística descritiva e a análise fatorial exploratória. Os resultados apontam que na área de Engenharia os respondentes do sexo feminino valorizaram mais as âncoras Estilo de Vida e Segurança/Estabilidade, cujos atributos estão socialmente associados ao gênero. Na área de Saúde, os respondentes do sexo masculino valorizaram mais as âncoras Autonomia/Independência, Desafio Puro e Criatividade Empreendedora, cujos atributos estão associados ao gênero. Conclui-se que as escolhas profissionais estão fortemente associadas aos valores e atributos socialmente atribuídos ao gênero.

Palavras-chave: Âncoras de carreira. Gênero. Profissões. Saúde. Engenharia.

\section{Un estudio de las relaciones entre género y anclas de carrera}

\section{Resumen}

El objetivo de la investigación fue analizar la relación entre género y anclas de carrera de estudiantes de cursos de graduación. El método de investigación elegido fue la encuesta (survey). La muestra sumó 251 estudiantes del área de Ingeniería y 251 del área de la Salud. Los datos fueron recolectados a través de cuestionarios que contenían el “Inventario de Orientación de Carrera” de Schein (1990). Las técnicas de análisis utilizadas fueron la estadística descriptiva y el análisis factorial exploratorio. Los resultados apuntan que, en el área de Ingeniería, los encuestados del género femenino valorizaron más las anclas Estilo de Vida y Seguridad/Estabilidad, cuyos atributos están socialmente asociados al género femenino. En el área de la Salud, los encuestados del sexo masculino valoraron más las anclas Autonomía/Independencia, Desafío Puro y Creatividad Emprendedora, cuyos atributos están asociados al género masculino. Concluimos que las elecciones profesionales están fuertemente asociadas a los valores y atributos socialmente atribuidos al género.

Palabras clave: Anclas de carrera. Género. Profesiones. Salud. Ingeniería. 


\section{INTRODUCTION}

This article analyzes the relationship between gender and career anchors among undergraduate students majoring in courses in which either the female or the male gender predominates. We start from the conclusions of Gubler, Biemann, Tschopp and Grote (2015) on the complex relationship between career anchors and the sociodemographic variables gender, ethnicity, and social class. We selected gender as a variable to analyze the possible career trajectories of individuals, showing the theoretical and practical relevance of the anchors, so as to broaden the understanding of their application.

We adopted the "Career Orientations Inventory" (COI) elaborated by Schein (1990) as a model of analysis, assuming that it is possible, based on the study of anchors choices, to identify attitudes and behaviors socially associated with genders, which contribute to limit the occupational spaces that may or may not be occupied by different subjects. This, in turn, leads to segregation and sustain inequalities in the socioeconomic relations in which they are involved (CHIES, 2010; FERREIRA, SAAVEDRA, TAVEIRA et al., 2013).

Barclay, Chapman and Brown $(2013)$ and Chapman $(2009,2015)$ warn that to study career anchors, one must first glance at what these authors call career approach. In their view, the approach includes two modalities of career orientation: the external and the internal. The first one studies the careers based on the history of the opportunities and limitations presented by the labor market, whereas the second examines how people create meanings in interactions with other people, their work, and the organizations. This paper focuses on the latter case, that is, the subjective nature of careers and the way individuals perceive their own anchors.

For Schein $(1990,1992,1996)$, career anchors are a combination of perceived areas of competence, motives, and values relating to professional work choices, which partly explain career paths chosen by individuals. Schein and Van Maanen (2016) point out that contemporary youngsters have rejected traditional careers that involve, for example, loyalty and acceptance of authority, favoring those that provide a sense and an opportunity to express their own talents. In addition, they have been demanding protection rights against discrimination motivated by arbitrary bases such as gender, sex, race, sexual preference, age, religion, and ethnicity. This corroborates the statements of Schulz and Enslin (2014) when they argue that gender continues to play an essential role in the gap between career choices and occupations.

Härkönen, Manzoni and Bihagen (2016) reveal that most research on gender inequalities in the labor market have identified significant women's disadvantage, based on the fact that men are better rewarded at the workplace in terms of income, status, and promotion. Authors such as Heckert, Droste, Adams et al. (2002), Ransom and Oaxaca (2005), and Watt (2010) have emphasized the existence of systemic gender discrimination, which to some extent explains the substantial discrepancies in status and payment, as well as the fact that women face more difficulties to advance to executive-level positions. As Bruschini (2007) and Chies (2010) explain, women have been mainly offered positions of lower social status, and even when they achieve positions in traditionally male areas, they are perceived as inferior.

Therefore, it is in the field of professional choice and the insertion in the labor market that gender inequalities express themselves more strongly, giving careers quite specific contours (CHIES, 2010). The notion of gender goes beyond the reproductive functions since the differences between men and women are socially constructed (MATTOS, 2010). From this perspective, gender is not something one is; it is something one does, that is, a sequence of acts (BUTLER, 2003).

This investigation on gender, based on career anchors, allows understanding the relationship between culture conditions and labor relations and provides inputs for educational and human resources institutions to develop policies to combat discrimination and segregation, by instrumentalizing managers to make decisions grounded on justice and equality. The method adopted in this study was the survey of students of both genders, of undergraduate courses in which the male or female gender predominates, enrolled in the Federal University of Minas Gerais (UFMG).

Based on data provided by the UFMG Dean's Office for Undergraduate Studies, which are not publicly available, we found that the health area concentrated the largest number of female courses, while the engineering area was predominantly male. The health courses that agreed to participate in the study were nursing, nutrition, biomedicine, and physiotherapy. The engineering courses were production, mechanics, and metallurgy. 
This article is divided into five sections, including this introduction. In the second section, we develop the theoretical framework, addressing the following topics: gender and career relations; career; and the notion of anchor. In the third section, the methodology is described. In the fourth section, we present and analyze the data collected. The fifth and last section presents the final remarks, with suggestions for future studies that will allow us to further the analysis of the data collected in the quantitative stage of this research.

\section{GENDER AND CAREER RELATIONS}

Feminist theories emphasize that the labor market reflects the social reality of gender stereotypes. This results in discrimination against women since employment situations and career choices stem from a gender-biased socialization process, through which the best employment and career opportunities are "naturally" offered to males (CEBRIÁN and MORENO, 2015).

In their studies, Gobillon, Meurs and Roux (2015) concluded that women have significantly lower access to the highest-paying jobs and that highly qualified men are more often hired than women who are highly qualified for high-paying positions.

Magee (2015) and Rice and Barth (2016) explain that gender stereotypes are prominent in many cultures and that, while societies change over time, these remain naturalized. According to the authors, there is a substantial underrepresentation of women in the fields of science, technology, engineering, and mathematics, as well as in business and social positions that require strong leadership skills. In addition, they are less likely to be promoted in the short term and are subject to evaluation standards that favor the male gender.

In Brazil, the insertion of a larger number of women into occupations that were exclusively male began in the 1970s (BRUSCHINI, 2007), but segregation still exists. In engineering, for example, greater women's participation occurred in certain specialties, such as production and chemical engineering (CHIES, 2010). In medicine, the female presence is higher only in the fields of pediatrics, dermatology, gynecology, and hematology (BRUSCHINI and LOMBARDI, 2000). In the other health professions, the female presence is predominant, since their activities are associated with "caring" and "serving," besides being socially understood as a vocation and extension of the work performed in the domestic and family spheres (CHIES, 2010). Therefore, one can affirm that social stereotypes continue to mark the spaces occupied by men and women in the various occupations (HECKERT, DROSTE, ADAMS et al., 2002; ALVES, 2009; WATT, 2010).

This study emerged from these findings and aimed to analyze the segregations and inequalities in professions regarded as more appropriate to the female or male genders, based on the identification of the career anchors.

\section{CAREER: CONCEPTS AND ANCHORS}

The career concepts more broadly discussed and adopted are those of Anglo-American origin. However, as Delhvi and Süß (2016) warn, they may not be transferable or applicable to other countries. This requires further research to expand the understanding of how professions and careers vary across cultures and in different contexts.

Bravo, Seibert, Kraimer et al. (2015) argue that experts and scholars of have observed that the rapid changes in the world in terms of global trade, technology, organizational design, and diversity of the workforce have led to changes in labor relations, employee-company relationships, and the notion of career grounded on the more traditional view of employment stability and linear and upward progression.

For Schein (1990), these findings refer to the following question: should organizations invest in career management systems that build a stable environment for the employee or should they look for a new set of concepts for the hiring system that facilitates the entry and exit of employees? In response, the author proposes to investigate further not only the changing nature of work but also the self-image that employees construct from their own socio-professional lives, through what he called COI, whose typology is intended to help people decipher their priorities and negotiate career management with organizations. 
The first five anchors were identified by Schein $(1974,1978)$ in studies conducted in the 1970s, and the last three were added from studies conducted in the late 1980s (SCHEIN, 1990, 1992). The following paragraphs describe each of them.

a) Security/Stability: people with this type of anchor are worried about finding a job or occupation that makes them economically secure and stable. Therefore, the content of the position in question is less important than the advantage of a good benefits program and a structured retirement plan.

b) Autonomy/Independence: the people identified with this anchor wish, above all, to be in control of their professional lives. Therefore, they do not feel comfortable with routines, rules, uniforms, work schedules, as well as all other forms of organizational control.

c) Technical/Functional Competence: the self-perception of people with this anchor is built around specific talents and abilities. They prefer certain areas of expertise, occupying technical, consulting or specialized advice positions.

d) General Managerial Competence: people with this anchor need to have the ability to lead in order to achieve organizational goals effectively.

e) Entrepreneurial Creativity: the central need of people with this anchor is to produce something of their own and to express themselves through the results of their work and the use of their creativity.

f) Service/Dedication to a cause: people with this anchor are practically the extreme opposite of the previous ones since their concern revolves around other people, of a cause, ideal, or value.

g) Pure Challenge: Success means overcoming obstacles, for people with this anchor. They are motivated by solving problems and facing opponents.

h) Lifestyle: people with this anchor want flexibility in employment and integration between their individual needs, their family and their occupation, even if they must sacrifice their career somewhat.

More than 20 years after the COI was elaborated, Feldman and Bolino (1996) conducted a critical review of the model and concluded that individuals might have multiple career anchors at different intensities. Therefore, these authors disagree with the central assumption that anchors stabilize as individuals mature. The criticism by these authors has gained great repercussion in the literature, although they offer little empirical support for their claims, according to Barclay, Chapman, and Brown (2013). The authors also argue that the relationships between anchors tend to be complementary and are linked to the historical, social, and cultural origin of individuals.

In general, the studies on career anchors seek to update the conceptions of Edgar H. Schein. Rodrigues, Guest and Budjanovcanin (2013), Gubler, Arnold and Coombs (2014), Bravo, Seibert, Kraimer et al. (2015), and Chapman (2009, 2015), have shown that people who have a career orientation can develop their own ideas about what it means to have a successful career and take appropriate measures to adapt to work-related changes. For this reason, they concluded that the term "career orientation" was more appropriate than the "career anchor," for the first offered an updated version of the new frontiers of labor and its possibilities.

\section{METHODOLOGY}

The method adopted was the exploratory and transversal survey, considered appropriate for the study of opinions, values, and beliefs (BABBIE, 2001).

UFMG was chosen as the locus of the research for it plays a relevant role in the national education scenario and also provides easy access for the researchers. After identifying the areas of knowledge that concentrated the largest number of courses with male and female predominance (engineering and health, respectively), we sent a letter to the respective offices of undergraduate studies requesting authorization to carry out the research. The health courses that agreed to participate in the survey were nursing, nutrition, biomedicine, and physiotherapy. The engineering courses were production, mechanics, and metallurgy. 
Table 1 shows the number of students enrolled in the courses by gender, as well as the respective percentages.

Table 1

Number of students enrolled in UFMG courses, by gender

\begin{tabular}{lccccc}
\hline Course & Male & $\%$ & Female & $\%$ & Total \\
\hline Production Engineering & 234 & 57.4 & 174 & 42.6 & 408 \\
Mechanical Engineering & 741 & 88.5 & 96 & 11.5 & 837 \\
Metallurgical Engineering & 164 & 62.4 & 99 & 37.6 & 263 \\
Nursing & 39 & 9.1 & 390 & 90.9 & 429 \\
Nutrition & 35 & 11.9 & 258 & 88.1 & 293 \\
Biomedicine & 41 & 24.4 & 127 & 75.6 & 168 \\
Physiotherapy & 59 & 16.3 & 309 & 83.7 & 363 \\
\hline
\end{tabular}

Source: Elaborated by the authors.

Production engineering had higher female participation (42.6\%), followed by metallurgical engineering (37.6\%). The health courses presented low male representation, with biomedicine standing out (24.4\%).

Data collection was completed in June 2016, with a sample of 251 students in each area of knowledge, totaling 502 respondents. We chose to include in the sample only the students enrolled from the fifth period onwards, because they were in a more advanced stage of preparation for entering the labor market (at least $50 \%$ of the course credits completed).

The questionnaire contained the "Career Anchors Inventory" (SCHEIN, 1996), consisting of 40 items and one section of sociodemographic data. After the dates and schedules were arranged with the teachers, the test was performed through self-application followed by the immediate recollection of the completed questionnaires.

The scale provided the following alternatives to the question "How much is each statement true for you?": never true for me (1 point), less occasionally ( 2 points), more occasionally ( 3 points), more frequently ( 4 points), less frequently ( 5 points) and always true for me (6 points). Each statement was related to a career anchor, and each anchor had five associated questions.

The responses were recorded in a database using the SPSS software. We resorted to the modeling of structural equations with partial least squares (PLS), in order to test the construct validity and the reliability of the measurements (TABACHNICK and FIDEL, 2007), due to its greater robustness in estimating violation of data normality assumption. The analyses indicated patterns of reliability and validity within the typically accepted limits, which allowed the application of the statistical t-test for independent samples, in order to evaluate differences in the sets (gender and group).

Initially, data cleaning and data preparation were expanded, including the evaluation and treatment of missing data $(0.083 \%$ of the database), outliers (using the criterion of interquartile range and the Mahalanobis - $\mathrm{D}^{2}$ distance) and normality assumptions (skewness and kurtosis). Then, the Jarque-Bera test was applied, in order to guarantee the integrity of the database in relation to the proposed objectives. The outliers were maintained, as they do not affect the estimates and are valid cases of the population. The premise of normality was not met, which did not imply limitations, as the PLS approach and the t-tests were robust in this respect. Linearity was also evaluated through the analysis of the dispersion diagrams of 30 randomly selected pairs of variables.

We also applied procedures to verify the scale dimensionality, the measurement quality, and the construct validity, so as to identify the degree of adherence between the measurements performed and the theoretical constructs measured. Exploratory Factor Analysis (EFA) was applied to verify dimensionality and adherence of indicators, using orthogonal rotation when necessary (varimax). Several measures of adherence showed that the results and the conditions were favorable to the EFA technique, such as Kaiser-Oyer-Olkin (KMO) value higher than 0.80 , sample adequacy measures of the individual variables (MSA) higher than 0.70 , variance extracted higher than $60 \%$, and commonalities higher than 0.40 . 
Upon the application of the PLS model, the results were also favorable, since the average variance extracted (AVE) was higher than 0.400 and the coefficients of Cronbach's alpha and composite reliability (CC) were higher than the respective limits of 0.600. The exception was the anchor Technical Competence, of the "Career Anchors Inventory" (SCHEIN, 1996), which was just below the minimum in terms of AVE but achieved satisfactory results for CC. Therefore, the measures proposed presented adequate validity and reliability for the testing of this study hypotheses.

\section{PROFESSIONS, ANCHORS, NATURALIZATIONS, AND GENDER INEQUALITIES}

Male respondents from engineering courses accounted for $68 \%$ of the sample, and female respondents enrolled in health courses, $89 \%$. The female presence in the engineering courses reached $32 \%$, while the male presence in health courses reached $11 \%$. The data somewhat showed a higher insertion of women in courses in which male students predominate. This indicates that females are seeking social recognition and, at the same time, struggling to reduce the social stereotypes that continue to demarcate the spaces occupied by the male gender (HECKERT, DROSTE, ADAMS et al., 2002; WATT, 2010). On the other hand, it shows a certain level of difficulty and accommodation on the part of men to confront prejudice and insert themselves in spaces socially assigned for the female gender.

Most respondents of both genders were singles doing the fifth and seventh semesters of their undergraduate courses (76\% in engineering and $67 \%$ in health). The average age in both areas was 23 years old.

In engineering courses, $41 \%$ of students had a monthly family income of $\mathrm{R} \$ 10,200$ or more, and only $10 \%$ had less than $\mathrm{R} \$$ 1,020 . In healthcare courses, the situation practically reversed: $8 \%$ had a monthly family income of $R \$ 10,200$ or more, while $30 \%$ had an income of less than $R \$ 2,039$. These figures indicate that the investigated courses aimed at the population's health care were predominantly occupied by women of lower social classes, which corresponds to a negative legacy typical of women's occupations, according to Bruschini (2007). This information is confirmed by studies that highlight the low salaries of professionals in various healthcare courses, especially when compared to those of medical professionals (BARLEM, LUNARDI, BARLEM et al., 2012; LOTUFO and MIRANDA, 2007).

Watt (2010) points out that the presence of men in careers dominated by women tends to be less significant precisely because they have lower wages and statuses. Moreover, according to the author, men are not encouraged to pursue their interests and develop their skills in non-traditional domains. When they do, they are more likely to drop the course than women.

For Heckert, Droste, Adamns et al. (2002), when making career decisions, women already expect to be paid less than men, both when entering the job market and at the peak of their careers. Therefore, gender discrimination is one of the factors that best explain the pay gap (GOBILLON, MEURS and ROUX, 2015).

When comparing the female and male perceptions within each area (Table 2), we identified some differences evidencing that the professional choices derive from socially constructed representations of gender in terms of attitudes and behaviors regarded as more appropriate to the male or female gender (BRAVO, SEIBERT, KRAIMER et al., 2015). 
Table 2

Averages of career anchors, in the engineering and health areas, by gender

\begin{tabular}{cccccccccc}
\hline \multirow{2}{*}{ Anchor } & \multicolumn{4}{c}{ Engineering Courses } & \multicolumn{5}{c}{ Health Courses } \\
\cline { 2 - 10 } & Male & Female & Difference & Total & Male & Female & Difference & Total \\
\hline Lifestyle & 4.27 & 4.59 & -0.32 & 4.37 & 4.50 & $4.57 a$ & -0.07 & 4.56 \\
Security & 4.03 & 4.41 & -0.38 & 4.16 & 4.38 & $4.54 a$ & -0.16 & 4.52 \\
Technical & 4.08 & 4.12 & -0.04 & 4.09 & 4.53 & 4.36 & 0.17 & 4.38 \\
Pure Challenge ${ }^{\text {ns }}$ & 3.94 & 3.88 & 0.06 & 3.92 & 4.35 & 3.90 & 0.45 & 3.95 \\
Autonomy & 3.65 & 3.69 & -0.04 & 3.66 & 4.20 & 3.70 & 0.50 & 3.75 \\
Service & 3.43 & 3.44 & 0.01 & 3.43 & 4.07 & 4.31 & -0.24 & 4.28 \\
Creativity & ns & 3.23 & 3.24 & -0.01 & 3.23 & 3.41 & 3.11 & 0.30 & 3.14 \\
Management & 3.20 & 3.22 & -0.02 & $3.21 f$ & 2.82 & 2.82 & 0.00 & 2.82 \\
\hline
\end{tabular}

Source: Elaborated by the authors.

$n s$ indicates differences that are not statistically significant between groups with $5 \%$ significance.

* Two-tailed t-tests were applied to compare the columns assuming equal variances with $5 \%$ significance level.

For each significant pair, the letter of the category with the lowest average appears under the value of the category with the highest average.

According to the data in Table 2, the three highest average anchors (Lifestyle, Security/Stability, Technical/Functional Competence) are the same for students in both areas.

The anchor that ranked first in the health (4.56) and engineering (4.37) areas was Lifestyle, with a slightly higher mean in the self-perception of the female representatives of both fields (Engineering $=4.59$, Health 4.57). This confirms this anchor's preponderance trend, already evidenced by Schein (1996), as a reflection of the changes in social values and the structure of the workforce, which began to manifest itself as a growing number of women joining organizations. The difference in selfperception between genders was much higher in engineering, confirming that female representatives are more concerned about integrating their professional lives with the other spheres of private life, such as family and friends (KNIVETON, 2004; HECKERT, DROSTE, ADAMS et al., 2002). The first evidence of inequality motivated by gender segregation was identified precisely in this result, that is, the reasons why the professions of this area are considered more socially appropriate to the female gender.

Throughout history, the free and invisible work associated with children's education and domestic routine has been understood as a feminine duty, a perception that remains in force in spite of the possible ruptures with the traditional model, which places men as responsible for the public sphere and women for the private space (HIRATA and KERGOAT, 2007). Therefore, the balance between private and professional life concerns women to a greater extent. Not rarely, they suffer from guilt when choose to enter the labor market, hence giving up a life dedicated exclusively to the household (VIEIRA and AMARAL, 2013).

The second anchor with the highest mean in both areas was Security/Stability (Engineering = 4.16; Health = 4.52), which reached a slightly higher score in the health area and the women's self-perception (Health $=+0.16$; Engineering $=+0.38$ ), resulting in the second evidence of inequality and segregation. This means that women tend to choose professions and careers that guarantee security and stability since they feel more comfortable in environments where routines, rules, uniforms, and other types of organizational control prevail. (HECKERT, DROSTE, ADAMS et al., 2002). This protective attitude and aversion to risk can lead them to accept positions of lower social status, which furthers gender inequality, as pointed out by Härkönen, Manzoni and Bihagen (2016). These considerations, coupled with the low salaries received by health professionals in Brazil (BARLEM, LUNARDI, BARLEM et al., 2012; LOTUFO and MIRANDA, 2007), point to a weak fight by women against gender discrimination and domination (WATT, 2010).

According to Schein $(1990,1992)$, Security/Stability is opposite to Autonomy/Independence, which ranked sixth in the health area (3.75) and fifth in engineering, and presented the most significant difference between genders in the health 
area $(m e n=4.20 ;$ women $=3.70)$. People who identify with the Autonomy/Independence anchor are driven by the desire to live freely and prefer to leave paid employment for careers that allow them to define for themselves what their areas of interest are (FELDMAN and BOLINO, 1996). It should be noted that although this need is less significant for the female gender in the health area $(m=4.20, f=3.70)$, the gender situation practically equaled $(m=3.65 ; f=3.69)$. The fact that women are taking risks by working in an area where male professionals predominate already indicates a greater need to be in control of their career. Therefore, this attribute indicates that women who wish to belong to a professional group dominated by men need to present characteristics socially associated with the male gender.

One can affirm that the dilemma experienced by subjects at the beginning of their careers, as identified by Schein (1990, 1992), of having to choose between autonomy or higher wages, on the one hand, and security or lower wages, on the other, may be untrue, as low wages are often offered to female workers (MAGEE, 2015), even when they work in the same area. In this sense, when considering the stereotypes, attitudes and behaviors expected from both genders, we can conclude that the possibility of choice expressed in the aforementioned dilemma does not only concern the condition of being young and having to enter the labor market but also to the limitations attributed to the self-perception of possibilities and the boundaries established by socially constructed gender relations. As Bimrose (2008) and Raley and Bianchi (2006) warn, the family develops in children conceptions about the behaviors and vocational choices regarded as most appropriate for boys and girls from the early childhood, exerting a strong influence on their future careers. This situation is aggravated in the Brazilian context, where the patriarchal model of society, in which the father is the highest and unquestionable authority, is still in force, sustaining the use of violence by men and the women's obedience and subordination (SAFIOTI, 2001; MIGUEL, 2017). Therefore, it is no coincidence that women are still more closely linked to the activities of caring and educating, conveyed by professions associated with academic courses such as nursing, nutrition and physiotherapy, while men, due to their authority, decisionmaking and "innate" leadership, are inserted in professions pertaining to courses such as engineering, law, and medicine (BRUSCHINI and LOMBARDI, 2000; ALVES, 2009; CHIES, 2010; FIGUÊREDO and CRUZ, 2017).

The third anchor with the highest average for the two areas was Technical/Functional Competence, whose opposite end is General Managerial Competence. The two anchors are associated with the second existential dilemma that mobilizes the personalities of subjects, according to Schein $(1990,1992)$ : to perform their original profession or to develop other skills and achieve a managerial position. This would explain the fact that General Managerial Competence ranked last in both areas of knowledge (Engineering $=3.21$; Health $=2.82$ ), not presenting this time any gender differences in the health area and +0.02 in engineering and women's perception. This means that the self-concept among engineering and health students is built around specific, individually developed talents or skills, and they will resist assuming supervisory and coordinating positions, as evidenced in the research conducted by Peres, Rocha, Hipólito and Calixto (2014).

People with a poor managerial anchor have low entrepreneurial intentions, as Lee and Wong (2004) point out, and prefer to take fewer risks, for to achieve results managers have to become dependent on other individuals, according to Faro, Amorim, Trevisan et al. (2010). In this study, the anchor Entrepreneurial Creativity ranked second to last in both engineering $(3,23)$ and health $(3,14)$, with a difference of 0.3 points among male respondents in the health area.

In the fourth and fifth places, there was a reversal of the position, with the anchor Service/Dedication to the Cause ranking fourth among health students (4.28) and fifth in the engineering area $(3,43)$, and vice versa for Pure Challenge (Health $=3.95$, fifth place; Engineering $=3.92$, fourth place).

It should be noted that the difference in perception was much higher for the female health students $(f=4.31)$ when compared to engineering $(f=3.44)$. The third evidence of inequality and professional segregation was identified from this result, especially as caring and serving are socially understood as forms of vocation and extension of the work carried out in the domestic and family spheres (CHIES, 2010).

This anchor is characteristic of people whose personality traits are linked to values that motivate them to make the world a better place (SCHEIN, 1990, 1996). Therefore, they usually seek professions in which the practice of helping human beings is valued, such as those associated with nursing, nutrition and physiotherapy courses, among others. However, as Schein (1990) warns, this anchor may be present in professions aimed, for example, at developing a product or technology that brings benefits to the population or creating a more humane working environment for people in organizations. This explains their 
presence in the field of engineering as well, albeit with lower incidence. However, there is a crucial difference in the sense that care acquires in each professional field, as explained by Hugman (1991). According to the author, nurses and physiotherapists perform the act of caring as a commitment ("to care for") because they are concerned about people, while lawyers, doctors, and engineers perform the act of caring as a task ("to care about"), as their professions require more rationality and emotional detachment from everyday activities. These attributes are naturalized as masculine and women need to incorporate them when they wish to enter into traditionally male strongholds.

The Pure Challenge anchor presented a positive difference of 0.45 among males in the health area and 0.06 in engineering. Hence, we highlight the fourth and final evidence of a tendency towards the naturalization of discretionary gender behavior, revealing that men are more likely to face obstacles and solve problems than women. In addition, the small difference between gender perceptions in the engineering area indicates that students are more identified with the behavior of their professional group than with the traditional role associated with the female gender. As stated earlier, when entering traditionally masculine strongholds, women must internalize and assume behaviors regarded as socially appropriate to this gender (CORSINI and SOUZA FILHO, 2004). What confirms this research assumption is the fact that the difference of perception between genders in the engineering area was only significant in the Lifestyle and Security anchors. In the other ones, the difference was insignificant. In the health area, on the other hand, differences in perception between genders were much higher for practically all anchors, especially Pure Challenge and Autonomy/Independence. This also proves that men are more resistant against identifying themselves with professions socially regarded as feminine (HECKERT, DROSTE, ADAMS et al., 2002).

In summary, the results of the studies confirm the trend that women's choices are socially directed to jobs and occupations that meet the socially-assigned needs of the female gender, such as finding the balance between work and family life (Lifestyle); achieving security and stability in employment (Security/Stability); and being able to dedicate to a social cause (Service/Dedication to a cause). They also confirm that women tend to take fewer risks in the labor market, hence fostering segregation. This fact also refers to the scenario where women achieve inferior professional status and are paid lower wages, even when working in the same professional area.

On the other hand, men show more desire to live freely and pursue their careers (Autonomy/Independence), being able to undertake (Entrepreneurial Creativity) and occupy challenging positions, in which the ability to overcome obstacles and solve problems (Pure Challenge) is regarded as an "innate" attribute of the male gender.

\section{CONCLUSION}

In this study, the career anchors inventory was used as an auxiliary tool to understand the relationship between gender and professional choices. We started from the assumption that it is possible to identify attitudes and behaviors socially associated with the genres that contribute to delimit professional spaces, generate segregation, and maintain inequalities in labor relations.

The research carried out with students of undergraduate courses in the area of engineering and health, in which the male and female genders predominate, respectively, confirmed the preponderance of the Lifestyle anchor in both fields, as a reflection of increased entry of women in organizations. Furthermore, it showed that such concern is higher among women since it places greater pressure on them to reconcile professional activities with household responsibilities. Therefore, this was the first evidence to confirm the research assumption.

The second evidence was identified through the health students' preference for the Security/Stability anchor, indicating a preference for choosing positions in which routines and rules prevail, along with limited autonomy, independence, and selfcontrol. These positions traditionally offer lower social status, tending to aggravate gender pay gaps in Brazilian society.

The willingness to take risks and seek autonomy and independence, on the contrary, would indicate a desire to fight against gender discrimination and domination. However, the low level of identification of health students with the Autonomy/ Independence anchor points that the fight against gender discrimination and domination needs to be strengthened and gain ground. 
The third evidence of inequality and segregation concerns the Service/Dedication to a cause anchor, whose difference of perception between genders was much higher among the female health students, especially since caring and serving is socially understood in this area as forms of vocation and extension of the work traditionally carried out by women in the domestic and family spheres.

The fourth and final evidence of a trend toward the naturalization of discretionary gender behavior was given by the Pure Challenge anchor, confirming that males are more likely to face obstacles and solve problems than females. In addition, the small difference between male and female perceptions in the field of engineering indicates that women appear, in this case, to identify more with the behavior of their professional group than with the traditional role attributed to the female gender. Therefore, this indicates that to enter spaces where men are the majority, women must assume behaviors regarded as socially appropriate to the male gender. At the same time, the significant difference between male and female perceptions regarding the importance of each anchor in the health area also indicates that men face greater difficulty in identifying with professions socially regarded as feminine.

In summary, from the anchor choices, it can be stated that women identify more with attributes socially associated with the female universe, such as caring for the family, low aggressiveness, and low willingness to take risks. Men, however, identify themselves with attitudes and behaviors associated with the masculine gender, such as independence, autonomy, challenge, and risk-taking. Therefore, one can affirm that social stereotypes continue to demarcate the spaces occupied by men and women in the various professions.

This study has questioned the dilemma described by Schein (1990), which states that youngsters at the beginning of their careers tend to opt for security and stability, even with low wages, to the detriment of autonomy and independence with higher incomes, for women tend to be paid lower wages than men even when in the same careers. Therefore, the option for security is more associated with the relations of gender discrimination and domination, built in and by the Brazilian patriarchal society, which legitimizes male violence and female subordination, hence generating professions designed for women, such as those linked to care and education, restricting their entry into other areas targeted at men, who are "innately" empowered for leadership, authority, and decision-making.

Schein's (1990) inventory has received much criticism, especially regarding the stability of the career anchors over time, in a social context of high volatility and mobility in labor markets. Due to these changes, critics wonder if instead of conducting quantitative studies to determine one's main anchor, people should not be asked what their career anchors are and whether the correct term should not be "career orientation." Here are some considerations in this regard. Firstly, this study agrees with Chapman $(2009,2015)$ when the author states that Schein's model may lack flexibility and be inaccurate in accommodating the current understandings of career orientation, since choosing a career is a complex decision, in which not only the subjects participate, but also the family and social group of which they are part. Secondly, it must be remembered that to reach the typology presented, Schein (1974) started from qualitative studies, conducted through interviews that sought to discover the motives, values, and attitudes that guide people to engage in tasks and activities of preference and expertise. Thirdly, the author made clear that the primary purpose of the typology was to help people to become self-aware so that they could orient themselves and acquire autonomy and security in the management of their careers. He also recommended that researchers, in addition to the $\mathrm{COI}$, conducted further interviews in their studies.

Other critics might say that the $\mathrm{COI}$ should only be answered by professionals who are already positioned in the market, not by students, because the anchors emerge and stabilize over time, with the accumulation of professional experience. Contrary to that argument, this study defends that in the past, individuals completed their undergraduate courses and quickly entered the labor market, remaining in a given organization until their retirement, if they wished so. In modern times, careers are no longer constructed in such a linear and orthodox way. It is, therefore, necessary that during school training, people seek to know themselves, by identifying their motives and abilities, as well as the various career paths available in the contemporary world, which are increasingly characterized by informal contracts. The range of undergraduate courses available has increased significantly and has made young people more anxious in the face of the various choices. It would be important for educational institutions to offer professional guidance services to help students identify different career paths, both preferred and possible, in the short, medium, and long terms. 
Labor organizations face yet another challenge: thinking about how to enable young people, especially women, to achieve success and career growth without having to relegate family and social life to the background. Finally, with regard to gender relations, the challenge posed to all involved is to propose spaces for addressing prejudice and gender inequality in a clear and transparent way, using the development of policies and strategies that might curb discrimination.

We suggest that future studies resort to the in-depth interview technique to explore the different nuances pointed out by the figures revealed by this research, such as why the Entrepreneurship and General Managerial Competence anchors present such low scores, and why students, in particular females, remain so willing to find a technical, traditional, and stable career. For comparative purposes, we also recommend that quantitative results be confirmed by surveys with various samples of respondents, including courses from other areas, as well as professionals already inserted in the labor market. 


\section{REFERENCES}

ALVES, T. Profissões sociais e gêneros: perspectivas em torno do debate sobre serviço social e profissões femininas. Locus Social, v. 2, p. 21-28, 2009.

BABBIE, E. Métodos de pesquisas de survey. Belo Horizonte: UFMG, 2001.

BARCLAY, W. B.; CHAPMAN, J. R.; BROWN, B. L. Underlying factor structure of Schein's Career Anchor Model. Journal of Career Assessment, v. 21, n. 3, p. 430-451, 2013.

BARLEM, J. G. T. et al. Opção e evasão de um curso de graduação em enfermagem: percepção de estudantes evadidos. Revista Gaúcha de Enfermagem, v. 33, n. 2, p. 132-138, 2012.

BIMROSE, J. Guidance for girls and women. In: ATHANASOU J. A.; ESBROEK, R. (Ed.). International handbook of career guidance. New York: Springer, 2008. p. 375-404.

BRAVO, J. et al. Measuring career orientations in the era of the boundaryless career. Journal of Career Assessment, v. 6, p. 1-11, 2015.

BRUSCHINI, C.; LOMBARDI, M. R. A bipolaridade do trabalho feminino no Brasil contemporâneo. Cadernos de Pesquisa, v. 110, p. 67-104, 2000.

BRUSCHINI, M. C. A. Trabalho e gênero no Brasil nos últimos dez anos. Cadernos de Pesquisa, v. 37, n. 132, p. 537-572, 2007.

BUTLER, J. Performative acts and gender constitution: an essay in phenomenology and feminist theory. In: BIAL, H. The performance studies reader. New York: Routledge, 2004. p. 154-166.

CEBRIÁN, I.; MORENO, G. The effects of gender differences in career interruptions on the gender wage gap in Spain. Feminist Economics, v. 21 , n. 4 , p. 1-27, 2015.

CHAPMAN, J. R. A partial response to Feldman and Bolino's critique. 2009. 82 f. Dissertation (Master Degree in Psychology) - Brigham Young University, Provo, 2009.

CHAPMAN, J. R. An empirically derived framework for conceptualizing Schein's career orientation theory. Journal of Career Assessment, v.24, n. 4, p. 669-684, 2015.

CHIES, P. V. Identidade de gênero e identidade profissional no campo de trabalho. Estudos Feministas, v. 18, n. 2, p. 510-528, 2010.

CORSINI, L.; SOUZA FILHO, E. A. Um estudo sobre as representações sociais de mulheres executivas: estilo de comportamento e de gestão. Cadernos de Psicologia Social do Trabalho, v. 7, p. 67-80, 2004.

DELHVI, S. S.; SÜß, S. Careers and career research in Germany: a literature review. Management Review Quarterly, v. 66, n. 1, p. 1-31, 2016.

FARO, E. S. C. et al. Âncoras de carreira e transformações no modelo de administração: estudo de caso do Tribunal de Contas da União (TCU). Cadernos EBAPE.BR, Rio de Janeiro, v. 8, n. 4, p. 710-733, 2010.

FELDMAN, D. C.; BOLINO, M. C. Careers within careers: reconceptualising the nature of career anchors and their consequences. Human Resource Management Review, v. 6, n. 2, p. 89-112, 1996.

FERREIRA, S. I. et al. Escolhas e planejamento de carreira: a tirania dos discursos tradicionais. Revista Brasileira de Orientação Profissional, v. 14, n. 2, p. 165-175, 2013.
FIGUERÊDO, R. B. de; CRUZ, F. M. L. Psicologia: profissão feminina? A visão dos estudantes de Psicologia. Estudos Feministas, v. 25, n. 2, p. 803-828, 2017.

GOBILLON, L.; MEURS, D.; ROUX, S. Estimating gender differences in access to jobs. Journal of Labor Economics, v. 33, v. 2, p. 317-363, 2015.

GUBLER, M.; ARNOLD, J.; COOMBS, C. Reassessing the protean career concept: empirical findings, conceptual components, and measurement. Journal of Organizational Behavior, v. 35, n. 1, p. 23-40, 2014.

GUBLER, M.; BIEMANN, T.; TSCHOPP, C.; GROTE, G. How career anchors differentiate managerial career trajectories. Journal of Career Development, v. 42. n.5, p. 412-430, 2015.

HÄRKÖNEN, J.; MANZONI, A.; BIHAGEN, E. Gender inequalities in occupational prestige across the working life: an analysis of the careers of West Germans and Swedes born from the 1920s to the 1970s. Advances in Life Course Research, v. 29, p. 41-51, 2016.

HECKERT, T. M. et al. Gender differences in anticipated salary: role of salary estimates for others job characteristics, career paths, and job inputs. Sex Roles, v. 47, n. 3-4, p. 139-151, 2002.

HIRATA, H.; KERGOAT, D. Novas configurações da divisão sexual do trabalho. Cadernos de Pesquisa, v. 37, n. 132, p. 595-609, 2007.

HUGMAN, R. Power in caring professions. London: The Macmillan Press, 1991.

KNIVETON, B. H. Managerial career anchors in a changing business environment. Journal of European Industrial Training, v. 28, n. 7, p. 564-573, 2004.

LEE, S.H.; WONG, P.K. An exploratory study of technopreneurial intentions: a career anchor perspective. Journal of Business Venturing, v. 19, n.1, p. 7-28, 2004.

LOTUFO, M.; MIRANDA, A. D. Sistemas de direção e práticas de gestão governamental em secretarias estaduais de saúde. Revista de Administração Pública, Rio de Janeiro, v. 41, n. 6, p. 1143-1163, 2007.

MAGEE, W. Effects of gender and age on pride in work, and job satisfaction. Journal of Happiness Studies, v. 16, n. 5, p. 10911115, 2015.

MATTOS, A. H. G. A ocupação feminina no mercado de trabalho: desafios para a gestão contemporânea das organizações. Gestão Contemporânea, v. 6, n. 6, p. 23-43, 2010.

MIGUEL, L. F. Voltando à discussão sobre capitalismo e patriarcado. Estudos Feministas, v. 25, n. 3, p. 1219-1237, 2017.

PEREZ, A. M.; ROCHA, J. R.; HIPOLITO, A. L. L.; CALIXTO, R. C. O conhecimento sobre a formação gerencial do enfermeiro: revisão integrative. Revista de Enfermagem da UFPE, v. 8, n. 2, p. 3700-3708, 2014.

RALEY, S; BIANCHI, S. Sons, Daughters, and Family Processes: Does Gender of Children Matter? Annual Review of Sociology, v. 32, p. 401-421, 2006.

RANSOM, M.; OAXACA, R. L. Intrafirm mobility and sex differences in wages. Industrial and Labor Relations Review, v. 58, n. 2, p. 219$237,2005$. 
RICE, L.; BARTH, J. M. Hiring decisions: the effect of evaluator gender and gender stereotype characteristics on the evaluation of job applicants. Gender Issues, v. 33, n. 1, p. 1-21, 2016.

RODRIGUES, R. A.; GUEST, D.; BUDJANOVCANIN, A. From anchors to orientations: towards a contemporary theory of career preferences. Journal of Vocational Behavior, v. 83, p. 142-152, 2013.

SAFFIOTI, H. I. B. Contribuições feministas para o estudo da violência de gênero. Cadernos Pagu, n. 16, p. 115-136, 2001.

SCHEIN, E. H. Career anchors and career paths: a panel study of management school graduates. Massachusetts: MIT Sloan School of Management, 1974. (Technical Report, n. 1).

SCHEIN, E. H. Career dynamics: matching individual and organizational needs. Reading: Addison-Wesley, 1978.

SCHEIN, E. H. Career anchors: discovering your real values. San Diego: University Associates, 1990.

SCHEIN, E. H. Career anchors and job/role planning: the links between career planning and career development. In: MONTROSS, D. H.;
SHINKMAN, C. J. (Ed.). Career development: theory and practice. Springfield: Charles C. Thomas, 1992. p. 207-218.

SCHEIN, E. H. Career anchors revisited: implications for career development in the 21st century. Academy of Management Perspectives, v. 10, p. 80-88, 1996.

SCHEIN, E. H.; VAN MAANEN, J. Career anchors and job/role planning. Organizational Dynamics, v. 45, n. 3, p. 165-173, 2016.

SCHULZ, D. J.; ENSLIN, C. The female executive's perspective on career planning and advancement in organizations. SAGE Open, v. 4, n. 4, p. 1-9, 2014.

TABACHNICK, B. G.; FIDELL, L. S. Using multivariate statistics. 5. ed. Boston, MA: Pearson/Allyn \& Bacon, 2007.

VIEIRA, A.; AMARAL, G. A. A Arte de ser beija-flor na tripla jornada de trabalho da mulher. Saúde e Sociedade, v. 22, p. 403-414, 2013.

WATT, H. M. Gender and occupational choice. In: CHRISLER, J. C.; MCCREARY, D. R. Handbook of gender research in psychology. New York: Springer, 2010. p. 379-400.

Adriane Vieira

ORCID: https://orcid.org/0000-0001-7552-5491

PhD in Administration from the Federal University of Minas Gerais (UFMG); Associate Professor for the Health Services Management Course of the Nursing School of the Federal University of Minas Gerais (UFMG), Belo Horizonte - MG, Brazil. E-mail: vadri.bh@gmail.com

Plínio Rafael Reis Monteiro

ORCID: http://orcid.org/0000-0002-5626-2945

PhD in Administration from the Federal University of Minas Gerais (UFMG); Adjunct Professor of the School of Economic Sciences of the Federal University of Minas Gerais (UFMG), Belo Horizonte-MG, Brazil. E-mail: preisufmg@gmail.com

Alexandre de Pádua Carrieri

ORCID: https://orcid.org/0000-0001-8552-8717

PhD in Administration from the Federal University of Minas Gerais (UFMG); Full Professor at the School of Economic Sciences of the Federal University of Minas Gerais (UFMG), Belo Horizonte -MG, Brazil. E-mail: aguiar.paduacarrieri@terra.com.br

Vanessa de Almeida Guerra

ORCID: https://orcid.org/0000-0001-5877-0030

PhD in Public Health from the School of Public Health (FSP) of the University of São Paulo (USP); Adjunct Professor III of the Nursing School of the Federal University of Minas Gerais (UFMG), Belo Horizonte - MG, Brazil. E-mail: vanessaalmeidaufmg@gmail.com

Luiz Carlos Brant

ORCID: https://orcid.org/0000-0003-1023-2385

PhD in Health Sciences, Fundação Oswaldo Cruz (FIOCRUZ); Adjunct Professor IV of the Nursing School of the Federal University of Minas Gerais (UFMG), Belo Horizonte - MG, Brazil. E-mail: brant.ufmg@gmail.com 